\title{
Molecular Regulation of Histamine Synthesis
}

\author{
Hua Huang ${ }^{1,2 *}$, Yapeng Li ${ }^{1}$, Jinyi Liang ${ }^{1,3}$ and Fred D. Finkelman ${ }^{4,5}$ \\ ${ }^{1}$ The Department of Biomedical Research, National Jewish Health, Denver, CO, United States, ${ }^{2}$ The Department of \\ Immunology and Microbiology, University of Colorado School of Medicine, Aurora, IL, United States, ${ }^{3}$ Department of \\ Parasitology, Zhongshan School of Medicine, Sun Yat-sen University, Guangzhou, China, ${ }^{4}$ The Division of Immunobiology, \\ Cincinnati Children's Hospital Medical Center, Cincinnati, OH, United States, ${ }^{5}$ The Division of Immunology, Allergy and \\ Rheumatology, Department of Medicine, University of Cincinnati College of Medicine, Cincinnati, OH, United States
}

Histamine is a critical mediator of lgE/mast cell-mediated anaphylaxis, a neurotransmitter and a regulator of gastric acid secretion. Histamine is a monoamine synthesized from the amino acid histidine through a reaction catalyzed by the enzyme histidine decarboxylase (HDC), which removes carboxyl group from histidine. Despite the importance of histamine, transcriptional regulation of HDC gene expression in mammals is still poorly understood. In this review, we focus on discussing advances in the understanding of molecular regulation of mammalian histamine synthesis.

Keywords: histamine, histidine decarboxylase, enhancers, promoter, gene regulation

\section{INTRODUCTION}

Bill Paul's impact on immunology is broad and enormous. Like many of his former trainees, I had the good fortune to learn from him. Bill's mentorship has nurtured my lifelong interest in studying type 2 immune responses that cause allergic diseases and protect against parasitic infections. In the early years of my laboratory, we had investigated how naïve $\mathrm{CD} 4^{+} \mathrm{T}$ cells commit into $\mathrm{T}$ helper type 1 cells by silencing the potential to transcribe the Il4 gene (1-3). More recently, we extended our efforts to understand how a bi-potential basophil and mast cell progenitor acquires the capacity to transcribe a set of basophil-specific or mast cell-specific genes while simultaneously repressing transcription of a gene set that is specific for the other cell type (4). With a newly gained understanding of a network of transcription factors and their targeted enhancers (5), our laboratory has chosen to investigate the $H d c$ gene (encode histidine decarboxylase, a rate-limiting enzyme for histamine synthesis) in greater detail.

Anaphylaxis is a serious allergic reaction that is rapid in onset and can be life threatening. The clinic manifestations include symptoms that involve the skin, gastrointestinal track, respiratory system, and cardiovascular system (6). Anaphylaxis can be caused by allergy to foods, insect venoms, medications, and other agents (6). The incidence of food-induced anaphylaxis has risen dramatically in developed countries during the past several decades (7-9). The cost of treating food allergy is estimated at about 25 billion dollars annually in the US alone (10).

Histamine plays an essential role in IgE-medicated anaphylaxis, the most common type of anaphylaxis (11-14). Histamine was first purified from ergot fungi (15) in 1910 and from human tissues (16) in 1927. Histamine has pleiotropic effects on skin and the cardiovascular, respiratory, digestive, central nervous, and immune systems (17). It is a profound vasodilator that increases blood vessel permeability, allowing blood leukocytes to enter tissues to promote inflammatory responses. Relatively large quantities of histamine can cause a rapid decrease in body temperature due to massive leakage of blood plasma into the extravascular space. Rapid release of large amounts of histamine leads to anaphylaxis $(12,14)$. Histamine belongs to a family of biogenic amines that 
includes neurotransmitters, such as serotonin and dopamine, and hormones, such as epinephrine. Biogenic amines that contain one or more amine groups are formed mainly by decarboxylation of amino acids. Histamine is a monoamine synthesized from the amino acid histidine through a reaction catalyzed by the enzyme histidine decarboxylase (HDC), which removes carboxyl group from histidine (Figure 1). Although histamine can be synthesized by bacteria found in contaminated food (18) and in the gut of asthma patients $(17,19)$, in this review, we focus on discussing advances in the understanding of molecular regulation of mammalian histamine synthesis.

\section{HISTAMINE-PRODUCING CELLS IN MAMMALS AND STIMULI THAT TRIGGER HISTAMINE RELEASE}

Histamine is synthesized primarily by mast cells, basophils, histaminergic neurons in the basal ganglia of the brain and enterochromaffin-like cells (ECL) in the stomach. These cells produce large amounts of histamine and are thought to be the major histamine-producing cells (Figure 2). They continuously synthesize histamine, which is then linked to the carboxyl group of heparin and stored in intracellular granules until the cells receive the appropriate activating stimulus. Upon external stimulation, these cells degranulate, releasing the stored histamine. Stimuli that trigger histamine release by these major histamineproducing cells have been reviewed extensively (20-25). Antigen crosslinking of antigen-specific IgE bound to the high-affinity IgE receptor, FceRI, on the mast cell and basophil surface is the most robust stimulus that triggers histamine release by these cells (20-23). Substance P and allergy-inducing drugs that bind to G-protein-coupled receptors can also trigger basophils and mast cells to release histamine via different signaling pathway $(23,26)$. In addition, complement components, such as the C3a and C5a "anaphylatoxins," have also been shown to induce histamine release by mast cells (27). Many cytokines, including IL-3, IL-18, IL-33, GM-CSF, and SCF, promote histamine synthesis (28-30). In general, cytokines alone do not induce histamine release although it remains controversial whether IL-33 can have this effect. Some reports describe that IL-33 stimulates histamine release $(31,32)$, while other reports dispute this $(33,34)$. It is suggested that IL-33 alone does not induce histamine release by basophils, but enhances histamine release in response to IgE/ FceRI crosslinking (35).

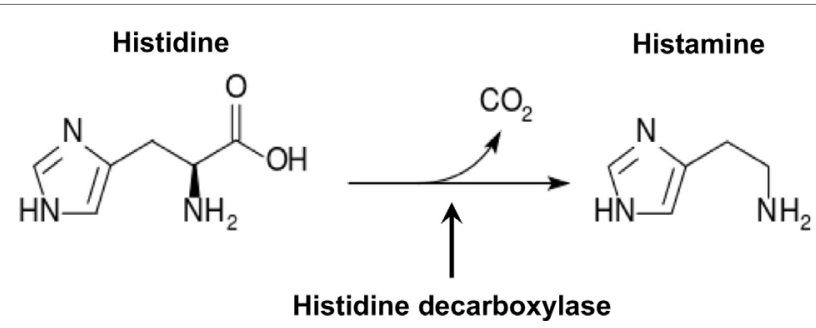

FIGURE 1 | Histamine synthesis.
Additional histamine-producing cells have also been identified, including T cells (36), dendritic cells (37), macrophages $(38,39)$, and epithelial cells $(40,41)$ (Figure 2$)$. In contrast to mast cells and basophils, these cells produce relative small quantities of histamine and do not store it in their cytoplasm (42). The small amounts of histamine that they produced are released without external stimulation (42). The biological significance of the small amounts of histamine produced by these minor histamine-producing cells remains unclear. Cell type-specific deletion of the $H d c$ gene, which encodes HDC, an enzyme essential for histamine synthesis, would shed light on the role of histamine synthesis and secretion by the minor histamineproducing cells.

\section{HDC AND HISTAMINE SYNTHESIS IN MAMMALS}

After several groups purified mammalian HDC protein from fetal rat liver and mouse mastocytoma P-815 cells (43-45), a cDNA that encodes this protein was subsequently cloned $(46,47)$. The $H d c$ gene encodes HDC protein, which has a molecular mass of $74 \mathrm{kDa}$ and is a proenzyme with little or no enzyme activity. Once the proenzyme is cleaved at the site near its c-terminus, presumably by Caspase- 9 , it yields a $53 \mathrm{kDa} \mathrm{N}$-terminal and a $20 \mathrm{kDa}$ C-terminal subunit. The $20 \mathrm{kDa}$ C-terminal subunit is believed to possess inhibitory activity (48). The $53 \mathrm{kDa} \mathrm{N}$-terminal subunit forms a homodimer that is an active decarboxylase $(48,49)$. HDC is the primary enzyme that catalyzes histamine synthesis. Mice deficient in the $H d c$ gene fail to synthesize histamine and have reduced or absent IgE-mediated anaphylactic responses (50-53). Several potent HDC inhibitors have been identified, including the histidine derivatives $\alpha$-fluoromethyl histidine, histidine methyl ester, and pirodoxal histidine methyl ester (54-56). However, these HDC inhibitors have not been further developed for clinical use.

\section{HDC GENE EXPRESSION AND HISTAMINE SYNTHESIS IN BASOPHILS AND MAST CELLS}

$H d c$ gene expression and histamine synthesis are regulated both positively and negatively by a range of factors. Notably, crosslinking of FceRI by antigen binding to FceRI-associated IgE increases mast cell $H d c$ mRNA expression and histamine synthesis $(57,58)$. These mast cell activation-induced increases in $H d c$ mRNA expression and histamine synthesis are also induced by phorbol 12-myristate 13-acetate (59). Hdc mRNA expression and histamine synthesis also increase as immature mast cells undergo maturation. Bone marrow-derived mast cells (BMMCs) appear immature because they contain relatively little histamine and express relatively low levels of FceRI (60). These immature mast cells develop into mature mast cells with higher amounts of histamine in vivo if they are adoptively transferred into the peritoneal cavity (61). However, it is not clear if in vivo exposure to IgE promotes maturation and increases $H d c$ mRNA expression. 


\section{Major Histamine-producing Cells}

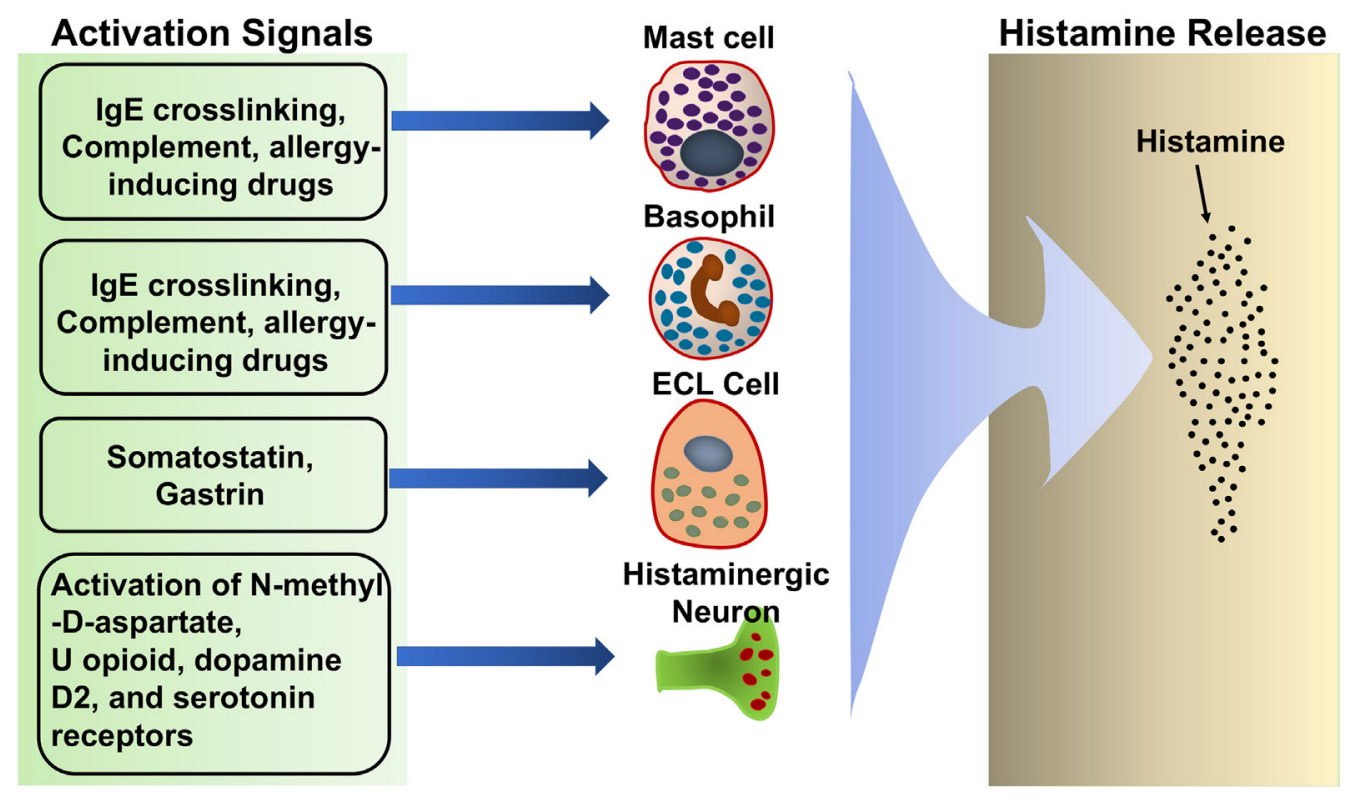

Minor Histamine-producing Cells

Dendritic Cells T Cells Macrophages Neutrophils Epithelial Cells
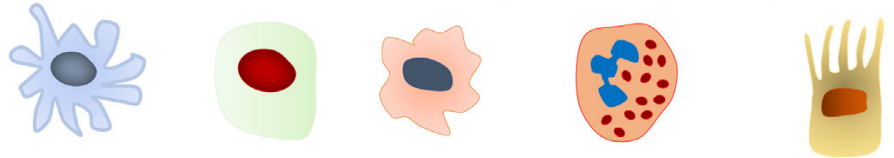

FIGURE 2 | Histamine-producing cells and stimuli that trigger histamine release.

In this regard, we demonstrated that chlorotoxin, which induces mast cell maturation (62), strongly upregulates $H d c$ gene expression in BMMCs within few hours after the treatment (5). The mechanism by which chlorotoxin enhances $H d c$ gene transcription remains to be determined. It is conceivable that chlorotoxin activates mast cells by binding to an acidic glycosphingolipid, ganglioside $\mathrm{G}$, that has been shown to be expressed on the mast cell surface (62). Chlorotoxin-triggered signals in mast cells then activate transcription factors that directly and rapidly promote $H d c$ gene transcription. It is unknown whether bacteria in the gut of allergic patients can promote $H d c$ mRNA and histamine synthesis by producing substances similar to chlorotoxin.

In line with the notion that factors promoting mast cell maturation also enhance histamine synthesis, cytokines that promote basophil and mast cell maturation, such as IL-3, IL-18, IL-33, GM-CSF, and SCF, have also been reported to increase HDC activity (28-30, 63). It is unclear whether these cytokines regulate $H d c$ gene transcription by increasing the expression of the genes that encode $H d c$ gene-activating transcription factors or by activating already expressed transcription factors to induce transcription of the $H d c$ gene. Other substances, including chemokines, neuropeptide substance P, and IL- $1 \alpha$ have also been reported to induce $H d c$ mRNA and histamine synthesis $(64,65)$.
By contrast, mitochondrial uncoupling protein 2, a mitochondrial transporter protein that transfers anions from the inner to the outer mitochondrial membrane and protons from the outer to the inner mitochondrial membrane, inhibits $H d c$ mRNA expression and histamine synthesis, possibly by suppressing the production of reactive oxygen species (66). Substances found in fruits and vegetables, such as quercetin (67), and in green tea, such as epigallocatechin gallate, also potently inhibit HDC (68). More detailed examination of negative regulators of $H d c$ mRNA expression should promote development of agents that may be able to prevent and treat food allergy and other histaminemediated allergic inflammatory disorders.

The human HDC gene is located in the 15q21.2 region of chromosome 15. It contains 12 exons (69) (Figure 3). Eight predicted isoforms can be generated by alternative splicing and two actual isoforms have been described (70). HDC mRNA is expressed broadly in many organs, with the highest expression levels found in the gallbladder, stomach, and lung (71). Because the RNA-seq data for normal tissues in the Human Protein Atlas were obtained from intact tissues, it is not clear whether the human $H D C$ gene is expressed predominantly in known histamine-producing cells, such as mast cells and ECL in high $H D C$-expressing tissues, or predominantly in other cell types in those tissues. In contrast to 


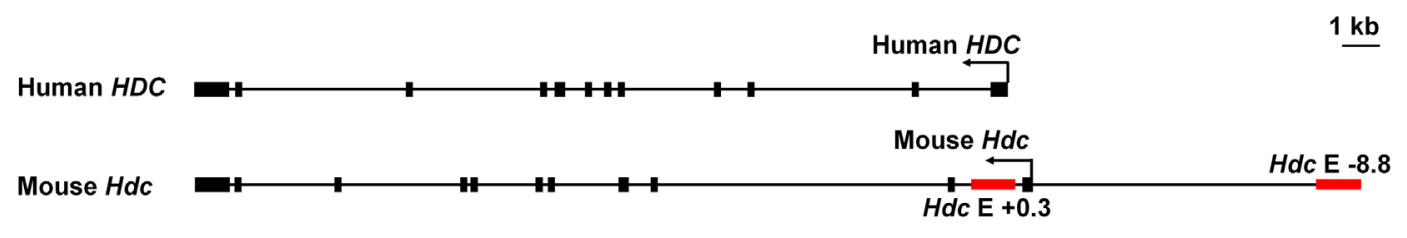

FIGURE 3 | Genomic structures of the human and mouse histidine decarboxylase (HDC) gene. Red bars indicate the enhancers we described.

the human $H d c$ gene, the mouse HDC gene is located in chromosome 2 (72). It resembles the human gene in that it contains 12 exons, is expressed broadly in many tissues with the highest expression levels in lung, ovary, and subcutaneous fat pads $(72,73)$, and is $86 \%$ homologous with the human gene (https:// www.ncbi.nlm.nih.gov/homologene/20490); however, there are only three predicted isoforms and no isoform, other than the classical one, have been found for murine $\mathrm{Hdc}$ (72).

There is still limited knowledge of how $H d c$ gene expression is regulated transcriptionally. Most previous work has concentrated on the promoter region of this gene. Deletion analysis of $H d c$ promoter-driven luciferase reporter gene transcription demonstrated that the transcription factor SP1 binds to a GC box (GGGGCGGGG) found in both the human and mouse $H d c$ gene promoters $(72,74)$. Several promoter elements have been reported to negatively regulate $H d c$ gene transcription. For example, the transcription factors YY1 and KLF4 have been shown to negatively regulate the $H d c$ gene by suppressing SP1 in a gastric cancer cell line $(75,76)$.

By contrast, $H d c$ gene expression is positively regulated by the transcription factor GATA binding protein 2 (GATA2), a member of the GATA family of transcription factors. GATA2 is critical for survival and proliferation of hematopoietic stem cells $(77,78)$, granulocyte-monocyte progenitor differentiation (79), and basophil and mast cell differentiation $(80,81)$ and is required for connective tissue mast cell development (5). By contrast, basophil development is not affected in connective tissue-specific Gata2-deficient mice (5). We have also found that mucosal and connective tissue-specific Gata2-deficient mice fail to develop both mucosal and connective tissue mast cells, indicating that GATA2 is required for both mucosal and connective tissue mast cell development (Li et al., unpublished data). To distinguish the role of GATA2 in regulating the $H d c$ gene from its role in mast cell development, we used an inducible gene deletion method to delete the Gata2 gene from mast cells after they had fully differentiated. In this inducible gene deletion model, the enzyme Cre is fused to the estrogen receptor (ER) and the ER-Cre fusion product is induced to enter the cell nucleus to cleave a floxed gene of interest by the ER ligand 4-hydroxytamoxifen (82). Using this method, we demonstrated that GATA2 plays a critical role in regulating $H d c$ gene expression in even fully differentiated mast cells. However, in contrast to its role in mast cell development, GATA2 is not needed for survival of fully differentiated mast cells (83).

More recently, our group has used active histone mark ChIP and reporter gene transcription assays to identify and characterize two Hdc enhancers in mast cells. Epigenomic studies demonstrate that monomethylation of lysine 4 on histone 3 (H3K4me1) marks genes that are poised to be transcribed, whereas acetylation of lysine 27 on histone $3(\mathrm{H} 3 \mathrm{~K} 27 \mathrm{ac}$ ) identifies genes that are actively being transcribed. The combined presence of H3K4me1 and H3K27ac modifications predicts enhancer activity (84-88). Our H3K4mel and H3K27ac ChIP-seq analysis of BMMCs identified two putative $H d c$ enhancers located $-8.8 \mathrm{~kb}$ upstream and $+0.3 \mathrm{~kb}$ downstream from the transcription start site of the $H d c$ gene (Figure 3). We demonstrated that the $-8.8 \mathrm{~kb} H d c$ enhancer, but not the $+0.3 \mathrm{~kb} \mathrm{Hdc}$ enhancer, increases minimal $H d c$ promoter activity in a luciferase reporter gene transcription assay. The transcription factor MITF binds to the $-8.8 \mathrm{Hdc}$ enhancer and drives its enhancer activity. Indeed, MITF overexpression largely restores $H d c$ gene expression in Gata2-deficient mast cells. Our study also suggests that GATA2 induces MITF and that these two transcription factors together direct full $H d c$ gene transcription in mast cells in a feed-forward manner. However, it is not certain that the $-8.8 \mathrm{~kb} H d c$ enhancer is fully responsible for positive regulation of the $H d c$ gene, because in vivo importance of the $+0.3 \mathrm{~kb} \mathrm{Hdc}$ enhancer in $H d c$ gene transcription cannot be ruled out by the luciferase reporter gene transcription assay alone (5).

Despite remarkable progress in genome-wide annotation of potential enhancers, functional validation of annotated enhancers remains an unmet challenge. Transgenic mice, reporter gene assay, and CRISPR/Cas9 genome editing have been used to validate the biological functions of enhancers identified by histone marks. Each of these methods has its strengths and weaknesses $(89,90)$. The reporter gene assay has been widely used to assess enhancer activity. It is simple, rapid, and efficient at assessing promoter and enhancer activity in transiently or stably transfected cell lines. The limitation of the transient reporter gene assay is that it does not measure promoter and enhancer activity in the context of chromatin. Despite this disadvantage, this reductionist approach is useful for assessing binding of transcription factors to cis regulatory elements in accessible regions. It has been reported that $\sim 60 \%$ of annotated enhancers show enhancer activity by the luciferase reporter gene assay $(86,91-94)$. The in vivo function of the $-8.8 H d c$ enhancer requires further investigation.

\section{HISTAMINE SYNTHESIS IN THE CENTRAL NERVOUS SYSTEM AND THE STOMACH}

In addition to its activity as a vasoactive mediation, histamine is a neurotransmitter and a regulator of gastric acid secretion. HDC mRNA is expressed in the brain exclusively in the basal ganglia (95). Specific ablation of histaminergic neurons leads to repetitive movements (96), that resemble the signs of Tourette syndrome (97). Consistent with this, a nonsense mutation at the human 
HDC gene (W317X) has been identified in a family of patients with this syndrome $(97,98)$ and mice completely deficient in $H d c$ gene transcription develop a Tourette-like syndrome (97, 99). However, the mechanisms involved in $H d c$ gene regulation in the basal ganglia are currently unknown. In the stomach, histamine is synthesized in ECL and is released from these cells upon gastrin and acetylcholine stimulation. The released histamine then stimulates parietal cells to secrete stomach acid $(25,100)$. Mice deficient in the $H d c$ gene fail to fully acidify their gastric contents (100), which can lead to indigestion, diarrhea, constipation, or rectal itching (101). Clinically, histamine $2\left(\mathrm{H}_{2}\right)$ receptor antagonists, such as ranitidine, are currently used to ameliorate stomach hyperacidity and peptic ulcer disease by blocking this receptor on the hydrochloric acid-producing parietal cells in the stomach (102). At present, it is not known how the $H d c$ gene is regulated in ECL. It is most likely that different transcription factors are used to regulate the $H d c$ gene in basal ganglia and ECL.

\section{CONCLUDING REMARKS}

Histidine decarboxylase is the rate-limiting enzyme for histamine synthesis. Understanding transcriptional regulation of the $H d c$

\section{REFERENCES}

1. Zhang Y, Apilado R, Coleman J, Ben-Sasson S, Tsang S, Hu-Li J, et al. Interferon gamma stabilizes the T helper cell type 1 phenotype. J Exp Med (2001) 194(2):165-72. doi:10.1084/jem.194.2.165

2. Zhuang Y, Huang Z, Nishida J, Brown M, Zhang L, Huang H. A continuous T-bet expression is required to silence the interleukin-4-producing potential in T helper type 1 cells. Immunology (2009) 128(1):34-42. doi:10.1111/ j.1365-2567.2009.03049.x

3. Huang H. Suppressing allergic immune responses. Front Biosci (2011) 3:864-70. doi:10.2741/e294

4. Qi X, Hong J, Chaves L, Zhuang Y, Chen Y, Wang D, et al. Antagonistic regulation by the transcription factors C/EBPalpha and MITF specifies basophil and mast cell fates. Immunity (2013) 39(1):97-110. doi:10.1016/j. immuni.2013.06.012

5. Li Y, Liu B, Harmacek L, Long Z, Liang J, Lukin K, et al. The transcription factors GATA2 and MITF regulate Hdc gene expression in mast cells and are required for IgE/mast cell-mediated anaphylaxis. J Allergy Clin Immunol (2017). doi:10.1016/j.jaci.2017.10.043

6. Simons FE. Anaphylaxis. J Allergy Clin Immunol (2010) 125(2 Suppl 2): S161-81. doi:10.1016/j.jaci.2009.12.981

7. Sicherer SH, Sampson HA. Food allergy. J Allergy Clin Immunol (2010) 125 (2 Suppl 2):S116-25. doi:10.1016/j.jaci.2009.08.028

8. Hogan SP, Wang YH, Strait R, Finkelman FD. Food-induced anaphylaxis: mast cells as modulators of anaphylactic severity. Semin Immunopathol (2012) 34(5):643-53. doi:10.1007/s00281-012-0320-1

9. Vickery BP, Chin S, Burks AW. Pathophysiology of food allergy. Pediatr Clin North Am (2011) 58(2):363-76, ix-x. doi:10.1016/j.pcl.2011.02.012

10. Gupta R, Holdford D, Bilaver L, Dyer A, Holl JL, Meltzer D. The economic impact of childhood food allergy in the United States. JAMA Pediatr (2013) 167(11):1026-31. doi:10.1001/jamapediatrics.2013.2376

11. Kemp SF, Lockey RF. Anaphylaxis: a review of causes and mechanisms. J Allergy Clin Immunol (2002) 110(3):341-8. doi:10.1067/mai.2002.126811

12. Finkelman FD. Anaphylaxis: lessons from mouse models. JAllergy Clin Immunol (2007) 120(3):506-15; quiz 516-7. doi:10.1016/j.jaci.2007.07.033

13. Strait RT, Morris SC, Yang M, Qu XW, Finkelman FD. Pathways of anaphylaxis in the mouse. J Allergy Clin Immunol (2002) 109(4):658-68. doi:10.1067/ mai.2002.123302

14. Reber LL, Hernandez JD, Galli SJ. The pathophysiology of anaphylaxis. J Allergy Clin Immunol (2017) 140(2):335-48. doi:10.1016/j.jaci.2017.06.003 gene will advance our knowledge about how this gene detects extracellular stimuli and increases its transcription, leading to histamine synthesis, replenishment, and accumulation that exacerbate allergic inflammation and anaphylaxis. Fine mapping of critical transcription factors and their authentic binding sites within the $H d c$ promoter and enhancers should promote identification of regulatory variants that influence allergy susceptibility and severity. Today, Bill Paul's teaching and his large body of work on IL-4 continues to inspire our fascination with type 2 immunity.

\section{AUTHOR CONTRIBUTIONS}

All authors contributed to the literature review and writing the paper.

\section{ACKNOWLEDGMENTS}

Research reported in this article was supported by grants from the National Institutes of Health R01AI107022 and RO1AI083986 (HH), R01AI113162 and R01AI130103 (FF), and a fund provided by Sun Yet-Sen University (JL).

15. Dale HH, Laidlaw PP. The physiological action of beta-iminazolylethylamine. J Physiol (1910) 41(5):318-44. doi:10.1113/jphysiol.1910.sp001406

16. Best $\mathrm{CH}$, Dale HH, Dudley HW, Thorpe WV. The nature of the vaso-dilator constituents of certain tissue extracts. J Physiol (1927) 62(4):397-417. doi:10.1113/jphysiol.1927.sp002369

17. O'Mahony L, Akdis M, Akdis CA. Regulation of the immune response and inflammation by histamine and histamine receptors. J Allergy Clin Immunol (2011) 128(6):1153-62. doi:10.1016/j.jaci.2011.06.051

18. Landete JM, De las Rivas B, Marcobal A, Munoz R. Updated molecular knowledge about histamine biosynthesis by bacteria. Crit Rev Food Sci Nutr (2008) 48(8):697-714. doi:10.1080/10408390701639041

19. Barcik W, Pugin B, Westermann P, Perez NR, Ferstl R, Wawrzyniak M, et al. Histamine-secreting microbes are increased in the gut of adult asthma patients. J Allergy Clin Immunol (2016) 138(5):1491-4.e1497. doi:10.1016/j. jaci.2016.05.049

20. Gilfillan AM, Tkaczyk C. Integrated signalling pathways for mast-cell activation. Nat Rev Immunol (2006) 6(3):218-30. doi:10.1038/nri1782

21. Caslin HL, Kiwanuka KN, Haque TT, Taruselli MT, MacKnight HP, Paranjape A, et al. Controlling mast cell activation and homeostasis: work influenced by Bill Paul that continues today. Front Immunol (2018) 9:868. doi:10.3389/fimmu.2018.00868

22. Gaudenzio N, Sibilano R, Marichal T, Starkl P, Reber LL, Cenac N, et al. Different activation signals induce distinct mast cell degranulation strategies. J Clin Invest (2016) 126(10):3981-98. doi:10.1172/JCI85538

23. Cildir G, Pant H, Lopez AF, Tergaonkar V. The transcriptional program, functional heterogeneity, and clinical targeting of mast cells. J Exp Med (2017) 214(9):2491-506. doi:10.1084/jem.20170910

24. Rapanelli M, Pittenger C. Histamine and histamine receptors in Tourette syndrome and other neuropsychiatric conditions. Neuropharmacology (2016) 106:85-90. doi:10.1016/j.neuropharm.2015.08.019

25. Hersey SJ, Sachs G. Gastric acid secretion. Physiol Rev (1995) 75(1):155-89. doi:10.1152/physrev.1995.75.1.155

26. McNeil BD, Pundir P, Meeker S, Han L, Undem BJ, Kulka M, et al. Identification of a mast-cell-specific receptor crucial for pseudo-allergic drug reactions. Nature (2015) 519(7542):237-41. doi:10.1038/nature14022

27. Woolhiser MR, Brockow K, Metcalfe DD. Activation of human mast cells by aggregated IgG through FcgammaRI: additive effects of C3a. Clin Immunol (2004) 110(2):172-80. doi:10.1016/j.clim.2003.11.007

28. Saluja R, Ketelaar ME, Hawro T, Church MK, Maurer M, Nawijn MC. The role of the IL-33/IL-1RL1 axis in mast cell and basophil activation in allergic 
disorders. Mol Immunol (2015) 63(1):80-5. doi:10.1016/j.molimm.2014. 06.018

29. Yoshimoto T, Tsutsui H, Tominaga K, Hoshino K, Okamura H, Akira S, et al. IL-18, although antiallergic when administered with IL-12, stimulates IL-4 and histamine release by basophils. Proc Natl Acad Sci U S A (1999) 96(24):13962-6. doi:10.1073/pnas.96.24.13962

30. Schneider E, Pollard H, Lepault F, Guy-Grand D, Minkowski M, Dy M. Histamine-producing cell-stimulating activity. Interleukin 3 and granulocytemacrophage colony-stimulating factor induce de novo synthesis of histidine decarboxylase in hemopoietic progenitor cells. JImmunol (1987) 139(11):3710-7.

31. Moulin D, Donze O, Talabot-Ayer D, Mezin F, Palmer G, Gabay C. Interleukin (IL)-33 induces the release of pro-inflammatory mediators by mast cells. Cytokine (2007) 40(3):216-25. doi:10.1016/j.cyto.2007.09.013

32. Silver MR, Margulis A, Wood N, Goldman SJ, Kasaian M, Chaudhary D. IL-33 synergizes with IgE-dependent and IgE-independent agents to promote mast cell and basophil activation. Inflamm Res (2010) 59(3):207-18. doi:10.1007/s00011-009-0088-5

33. Allakhverdi Z, Smith DE, Comeau MR, Delespesse G. Cutting edge: the ST2 ligand IL-33 potently activates and drives maturation of human mast cells. J Immunol (2007) 179(4):2051-4. doi:10.4049/jimmunol.179.4.2051

34. Andrade MV, Iwaki S, Ropert C, Gazzinelli RT, Cunha-Melo JR, Beaven MA. Amplification of cytokine production through synergistic activation of NFAT and AP-1 following stimulation of mast cells with antigen and IL-33. Eur J Immunol (2011) 41(3):760-72. doi:10.1002/eji.201040718

35. Fux M, Pecaric-Petkovic T, Odermatt A, Hausmann OV, Lorentz A, Bischoff SC, et al. IL-33 is a mediator rather than a trigger of the acute allergic response in humans. Allergy (2014) 69(2):216-22. doi:10.1111/all.12309

36. Kubo Y, Nakano K. Regulation of histamine synthesis in mouse CD4+ and CD8+ T lymphocytes. Inflamm Res (1999) 48(3):149-53. doi:10.1007/ s000110050438

37. Szeberenyi JB, Pallinger E, Zsinko M, Pos Z, Rothe G, Orso E, et al. Inhibition of effects of endogenously synthesized histamine disturbs in vitro human dendritic cell differentiation. Immunol Lett (2001) 76(3):175-82. doi:10.1016/ S0165-2478(01)00184-5

38. Takamatsu S, Nakashima I, Nakano K. Modulation of endotoxin-induced histamine synthesis by cytokines in mouse bone marrow-derived macrophages. Inflamm Res (1997) 46(Suppl 1):S91-2. doi:10.1007/s000110050106

39. Takamatsu S, Nakano K. Histamine synthesis by bone marrow-derived macrophages. Biosci Biotechnol Biochem (1994) 58(10):1918-9. doi:10.1271/ bbb.58.1918

40. Stegaev V, Nies AT, Porola P, Mieliauskaite D, Sanchez-Jimenez F, Urdiales JL, et al. Histamine transport and metabolism are deranged in salivary glands in Sjogren's syndrome. Rheumatology (Oxford) (2013) 52(9):1599-608. doi:10.1093/rheumatology/ket188

41. Maslinski C, Kierska D. Histamine in $\mathrm{C} 3 \mathrm{H} / \mathrm{W}$ mice carrying spontaneous tumors of the mammary gland. Agents Actions (1991) 33(1-2):192-4. doi:10.1007/BF01993164

42. Konttinen YT, Husu H, Han X, Passani MB, Ballerini C, Stegaev V, et al. Non-professional histamine producing cells, immune responses and autoimmunity. In: Stark H, editor. H4 Receptor: A Novel Drug Target in Immunoregulation and Inflammation. (2013). p. 201-58.

43. Taguchi Y, Watanabe T, Kubota H, Hayashi H, Wada H. Purification of histidine decarboxylase from the liver of fetal rats and its immunochemical and immunohistochemical characterization. J Biol Chem (1984) 259(8):5214-21.

44. Martin SA, Bishop JO. Purification and characterization of histidine decarboxylase from mouse kidney. Biochem J (1986) 234(2):349-54. doi:10.1042/ bj2340349

45. Ohmori E, Fukui T, Imanishi N, Yatsunami K, Ichikawa A. Purification and characterization of L-histidine decarboxylase from mouse mastocytoma P-815 cells. J Biochem (1990) 107(6):834-9. doi:10.1093/oxfordjournals. jbchem.a123134

46. Joseph DR, Sullivan PM, Wang YM, Kozak C, Fenstermacher DA, Behrendsen ME, et al. Characterization and expression of the complementary DNA encoding rat histidine decarboxylase. Proc Natl Acad Sci U S A (1990) 87(2):733-7. doi:10.1073/pnas.87.2.733

47. Yamamoto J, Yatsunami K, Ohmori E, Sugimoto Y, Fukui T, Katayama T, et al. cDNA-derived amino acid sequence of L-histidine decarboxylase from mouse mastocytoma P-815 cells. FEBS Lett (1990) 276(1-2):214-8. doi:10.1016/0014-5793(90)80545-T

48. Furuta K, Nakayama K, Sugimoto Y, Ichikawa A, Tanaka S. Activation of histidine decarboxylase through post-translational cleavage by caspase- 9 in a mouse mastocytoma P-815. J Biol Chem (2007) 282(18):13438-46. doi:10.1074/jbc.M609943200

49. Komori H, Nitta Y, Ueno H, Higuchi Y. Structural study reveals that Ser-354 determines substrate specificity on human histidine decarboxylase. J Biol Chem (2012) 287(34):29175-83. doi:10.1074/jbc.M112.381897

50. Ohtsu H, Tanaka S, Terui T, Hori Y, Makabe-Kobayashi Y, Pejler G, et al. Mice lacking histidine decarboxylase exhibit abnormal mast cells. FEBS Lett (2001) 502(1-2):53-6. doi:10.1016/S0014-5793(01)02663-1

51. Hallgren J, Gurish MF. Granule maturation in mast cells: histamine in control. Eur J Immunol (2014) 44(1):33-6. doi:10.1002/eji.201344262

52. Makabe-Kobayashi Y, Hori Y, Adachi T, Ishigaki-Suzuki S, Kikuchi Y, Kagaya Y, et al. The control effect of histamine on body temperature and respiratory function in IgE-dependent systemic anaphylaxis. J Allergy Clin Immunol (2002) 110(2):298-303. doi:10.1067/mai.2002.125977

53. Nakazawa S, Sakanaka M, Furuta K, Natsuhara M, Takano H, Tsuchiya S, et al. Histamine synthesis is required for granule maturation in murine mast cells. Eur J Immunol (2014) 44(1):204-14. doi:10.1002/eji.201343838

54. Kollonitsch J, Perkins LM, Patchett AA, Doldouras GA, Marburg S, Duggan DE, et al. Selective inhibitors of biosynthesis of aminergic neurotransmitters. Nature (1978) 274(5674):906-8. doi:10.1038/274906a0

55. Kelley JL, Miller CA, White HL. Inhibition of histidine decarboxylase. Derivatives of histidine. J Med Chem (1977) 20(4):506-9. doi:10.1021/ jm00214a009

56. Wu F, Yu J, Gehring H. Inhibitory and structural studies of novel coenzymesubstrate analogs of human histidine decarboxylase. FASEB J (2008) 22(3): 890-7. doi:10.1096/f.07-9566com

57. Castellani ML, Perrella A, Kempuraj DJ, Boucher W, Tagen M, Salini V, et al. Immunological activation of human umbilical cord blood mast cells induces tryptase secretion and interleukin-6, and histidine decarboxilase mRNA gene expression. Pharmacol Res (2007) 55(1):57-63. doi:10.1016/j. phrs.2006.10.006

58. Chhiba KD, Hsu CL, Berdnikovs S, Bryce PJ. Transcriptional heterogeneity of mast cells and basophils upon activation. J Immunol (2017) 198(12):4868-78. doi:10.4049/jimmunol.1601825

59. Nagashima Y, Kako K, Kim JD, Fukamizu A. Enhanced histamine production through the induction of histidine decarboxylase expression by phorbol ester in Jurkat cells. Mol Med Rep (2012) 6(5):944-8. doi:10.3892/mmr.2012.1049

60. Galli SJ, Dvorak AM, Marcum JA, Ishizaka T, Nabel G, Der Simonian H, et al. Mast cell clones: a model for the analysis of cellular maturation. J Cell Biol (1982) 95(2 Pt 1):435-44. doi:10.1083/jcb.95.2.435

61. Nakano T, Sonoda T, Hayashi C, Yamatodani A, Kanayama Y, Yamamura T, et al. Fate of bone marrow-derived cultured mast cells after intracutaneous, intraperitoneal, and intravenous transfer into genetically mast cell-deficient $\mathrm{W} / \mathrm{Wv}$ mice. Evidence that cultured mast cells can give rise to both connective tissue type and mucosal mast cells. J Exp Med (1985) 162(3):1025-43.

62. Katz HR, Levine JS, Austen KF. Interleukin 3-dependent mouse mast cells express the cholera toxin-binding acidic glycosphingolipid, ganglioside GM1, and increase their histamine content in response to toxin. J Immunol (1987) 139(5):1640-6.

63. Wang Z, Mascarenhas N, Eckmann L, Miyamoto Y, Sun X, Kawakami T, et al. Skin microbiome promotes mast cell maturation by triggering stem cell factor production in keratinocytes. J Allergy Clin Immunol (2017) 139(4):1205-16. e1206. doi:10.1016/j.jaci.2016.09.019

64. Conti P, Pang X, Boucher W, Letourneau R, Reale M, Barbacane RC, et al. Impact of Rantes and MCP-1 chemokines on in vivo basophilic cell recruitment in rat skin injection model and their role in modifying the protein and mRNA levels for histidine decarboxylase. Blood (1997) 89(11):4120-7.

65. Castellani ML, Ciampoli C, Felaco M, Tete S, Conti CM, Salini V, et al. Neuropeptide substance $\mathrm{P}$ induces mRNA expression and secretion of CXCL8 chemokine, and HDC in human umbilical cord blood mast cells. Clin Invest Med (2008) 31(6):E362-72. doi:10.25011/cim.v31i6.4923

66. Tagen M, Elorza A, Kempuraj D, Boucher W, Kepley CL, Shirihai OS, et al. Mitochondrial uncoupling protein 2 inhibits mast cell activation and reduces histamine content. J Immunol (2009) 183(10):6313-9. doi:10.4049/ jimmunol.0803422 
67. Kempuraj D, Castellani ML, Petrarca C, Frydas S, Conti P, Theoharides TC, et al. Inhibitory effect of quercetin on tryptase and interleukin- 6 release, and histidine decarboxylase mRNA transcription by human mast cell-1 cell line. Clin Exp Med (2006) 6(4):150-6. doi:10.1007/s10238-006-0114-7

68. Rodriguez-Caso C, Rodriguez-Agudo D, Sanchez-Jimenez F, Medina MA. Green tea epigallocatechin-3-gallate is an inhibitor of mammalian histidine decarboxylase. Cell Mol Life Sci (2003) 60(8):1760-3. doi:10.1007/ s00018-003-3135-3

69. Yatsunami K, Ohtsu H, Tsuchikawa M, Higuchi T, Ishibashi K, Shida A, et al. Structure of the L-histidine decarboxylase gene. J Biol Chem (1994) 269(2):1554-9.

70. Mamune-Sato R, Yamauchi K, Tanno Y, Ohkawara Y, Ohtsu H, Katayose D, et al. Functional analysis of alternatively spliced transcripts of the human histidine decarboxylase gene and its expression in human tissues and basophilic leukemia cells. Eur J Biochem (1992) 209(2):533-9. doi:10.1111/ j.1432-1033.1992.tb17317.x

71. Fagerberg L, Hallstrom BM, Oksvold P, Kampf C, Djureinovic D, Odeberg J, et al. Analysis of the human tissue-specific expression by genome-wide integration of transcriptomics and antibody-based proteomics. Mol Cell Proteomics (2014) 13(2):397-406. doi:10.1074/mcp.M113.035600

72. Suzuki-Ishigaki S, Numayama-Tsuruta K, Kuramasu A, Sakurai E, Makabe Y, Shimura S, et al. The mouse L-histidine decarboxylase gene: structure and transcriptional regulation by $\mathrm{CpG}$ methylation in the promoter region. Nucleic Acids Res (2000) 28(14):2627-33. doi:10.1093/nar/28.14.2627

73. Yue F, Cheng Y, Breschi A, Vierstra J, Wu W, Ryba T, et al. A comparative encyclopedia of DNA elements in the mouse genome. Nature (2014) 515(7527):355-64. doi:10.1038/nature13992

74. Hirasawa N, Torigoe M, Kano K, Ohuchi K. Involvement of Spl in lipopolysaccharide-induced expression of HDC mRNA in RAW 264 cells. Biochem Biophys Res Commun (2006) 349(2):833-7. doi:10.1016/j.bbrc.2006.08.104

75. Ai W, Liu Y, Wang TC. Yin yang 1 (YY1) represses histidine decarboxylase gene expression with SREBP-1a in part through an upstream Sp1 site. Am J Physiol Gastrointest Liver Physiol (2006) 290(6):G1096-104. doi:10.1152/ ajpgi.00199.2005

76. Ai W, Liu Y, Langlois M, Wang TC. Kruppel-like factor 4 (KLF4) represses histidine decarboxylase gene expression through an upstream Sp1 site and downstream gastrin responsive elements. J Biol Chem (2004) 279(10): 8684-93. doi:10.1074/jbc.M308278200

77. Ling KW, Ottersbach K, van Hamburg JP, Oziemlak A, Tsai FY, Orkin SH, et al. GATA-2 plays two functionally distinct roles during the ontogeny of hematopoietic stem cells. J Exp Med (2004) 200(7):871-82. doi:10.1084/ jem. 20031556

78. Lim KC, Hosoya T, Brandt W, Ku CJ, Hosoya-Ohmura S, Camper SA, et al. Conditional Gata2 inactivation results in HSC loss and lymphatic mispatterning. J Clin Invest (2012) 122(10):3705-17. doi:10.1172/JCI61619

79. Rodrigues NP, Boyd AS, Fugazza C, May GE, Guo Y, Tipping AJ, et al. GATA-2 regulates granulocyte-macrophage progenitor cell function. Blood (2008) 112(13):4862-73. doi:10.1182/blood-2008-01-136564

80. Tsai FY, Orkin SH. Transcription factor GATA-2 is required for proliferation/ survival of early hematopoietic cells and mast cell formation, but not for erythroid and myeloid terminal differentiation. Blood (1997) 89(10):3636-43.

81. Iwasaki H, Mizuno S, Arinobu Y, Ozawa H, Mori Y, Shigematsu H, et al. The order of expression of transcription factors directs hierarchical specification of hematopoietic lineages. Genes Dev (2006) 20(21):3010-21. doi:10.1101/ gad.1493506

82. Hayashi S, McMahon AP. Efficient recombination in diverse tissues by a tamoxifen-inducible form of Cre: a tool for temporally regulated gene activation/inactivation in the mouse. Dev Biol (2002) 244(2):305-18. doi:10.1006/dbio.2002.0597

83. Li Y, Qi X, Liu B, Huang H. The STAT5-GATA2 pathway is critical in basophil and mast cell differentiation and maintenance. J Immunol (2015) 194(9):4328-38. doi:10.4049/jimmunol.1500018

84. Rada-Iglesias A, Bajpai R, Swigut T, Brugmann SA, Flynn RA, Wysocka J. A unique chromatin signature uncovers early developmental enhancers in humans. Nature (2011) 470(7333):279-83. doi:10.1038/nature09692

85. Calo E, Wysocka J. Modification of enhancer chromatin: what, how, and why? Mol Cell (2013) 49(5):825-37. doi:10.1016/j.molcel.2013.01.038

86. Heintzman ND, Stuart RK, Hon G, Fu Y, Ching CW, Hawkins RD, et al. Distinct and predictive chromatin signatures of transcriptional promoters and enhancers in the human genome. Nat Genet (2007) 39(3):311-8. doi:10.1038/ ng1966

87. Creyghton MP, Cheng AW, Welstead GG, Kooistra T, Carey BW, Steine EJ, et al. Histone $\mathrm{H} 3 \mathrm{~K} 27 \mathrm{ac}$ separates active from poised enhancers and predicts developmental state. Proc Natl Acad Sci U S A (2010) 107(50):21931-6. doi:10.1073/pnas.1016071107

88. Spitz F, Furlong EE. Transcription factors: from enhancer binding to developmental control. Nat Rev Genet (2012) 13(9):613-26. doi:10.1038/nrg3207

89. Kellis M, Wold B, Snyder MP, Bernstein BE, Kundaje A, Marinov GK, et al. Defining functional DNA elements in the human genome. Proc Natl Acad Sci U S A (2014) 111(17):6131-8. doi:10.1073/pnas.1318948111

90. Shlyueva D, Stampfel G, Stark A. Transcriptional enhancers: from properties to genome-wide predictions. Nat Rev Genet (2014) 15(4):272-86. doi:10.1038/nrg3682

91. Koues OI, Kowalewski RA, Chang LW, Pyfrom SC, Schmidt JA, Luo H, et al. Enhancer sequence variants and transcription-factor deregulation synergize to construct pathogenic regulatory circuits in B-cell lymphoma. Immunity (2015) 42(1):186-98. doi:10.1016/j.immuni.2014.12.021

92. May D, Blow MJ, Kaplan T, McCulley DJ, Jensen BC, Akiyama JA, et al. Large-scale discovery of enhancers from human heart tissue. Nat Genet (2011) 44(1):89-93. doi:10.1038/ng.1006

93. Arnold CD, Gerlach D, Stelzer C, Boryn LM, Rath M, Stark A. Genomewide quantitative enhancer activity maps identified by STARR-seq. Science (2013) 339(6123):1074-7. doi:10.1126/science.1232542

94. Bonn S, Zinzen RP, Girardot C, Gustafson EH, Perez-Gonzalez A, Delhomme N, et al. Tissue-specific analysis of chromatin state identifies temporal signatures of enhancer activity during embryonic development. Nat Genet (2012) 44(2):148-56. doi:10.1038/ng.1064

95. Krusong K, Ercan-Sencicek AG, Xu M, Ohtsu H, Anderson GM, State MW, et al. High levels of histidine decarboxylase in the striatum of mice and rats. Neurosci Lett (2011) 495(2):110-4. doi:10.1016/j.neulet.2011.03.050

96. Rapanelli M, Frick L, Bito H, Pittenger C. Histamine modulation of the basal ganglia circuitry in the development of pathological grooming. Proc Natl Acad Sci U S A (2017) 114(25):6599-604. doi:10.1073/pnas.1704547114

97. Baldan LC, Williams KA, Gallezot JD, Pogorelov V, Rapanelli M, Crowley M, et al. Histidine decarboxylase deficiency causes Tourette syndrome: parallel findings in humans and mice. Neuron (2014) 81(1):77-90. doi:10.1016/j. neuron.2013.10.052

98. Ercan-Sencicek AG, Stillman AA, Ghosh AK, Bilguvar K, O’Roak BJ, Mason CE, et al. L-histidine decarboxylase and Tourette's syndrome. N Engl J Med (2010) 362(20):1901-8. doi:10.1056/NEJMoa0907006

99. Xu M, Li L, Ohtsu H, Pittenger C. Histidine decarboxylase knockout mice, a genetic model of Tourette syndrome, show repetitive grooming after induced fear. Neurosci Lett (2015) 595:50-3. doi:10.1016/j.neulet.2015. 03.067

100. Tanaka S, Hamada K, Yamada N, Sugita Y, Tonai S, Hunyady B, et al. Gastric acid secretion in L-histidine decarboxylase-deficient mice. Gastroenterology (2002) 122(1):145-55. doi:10.1053/gast.2002.30312

101. Saltzman JR, Kemp JA, Golner BB, Pedrosa MC, Dallal GE, Russell RM. Effect of hypochlorhydria due to omeprazole treatment or atrophic gastritis on protein-bound vitamin B12 absorption. J Am Coll Nutr (1994) 13(6):584-91. doi:10.1080/07315724.1994.10718452

102. Brogden RN, Carmine AA, Heel RC, Speight TM, Avery GS. Ranitidine: a review of its pharmacology and therapeutic use in peptic ulcer disease and other allied diseases. Drugs (1982) 24(4):267-303. doi:10.2165/ 00003495-198224040-00002

Conflict of Interest Statement: The authors declare that the research was conducted in the absence of any commercial or financial relationships that could be construed as a potential conflict of interest.

Copyright (C) 2018 Huang, Li, Liang and Finkelman. This is an open-access article distributed under the terms of the Creative Commons Attribution License (CC BY). The use, distribution or reproduction in other forums is permitted, provided the original author(s) and the copyright owner are credited and that the original publication in this journal is cited, in accordance with accepted academic practice. No use, distribution or reproduction is permitted which does not comply with these terms. 